\title{
Memory for Social Sustainability: Recalling Cultural Memories in Zanqit Alsitat Historical Street Market, Alexandria, Egypt
}

\author{
Fatmaelzahraa Hussein ${ }^{1,2, *(\mathbb{D})}$, John Stephens ${ }^{1}(\mathbb{D})$ and Reena Tiwari ${ }^{1}$ \\ 1 School of Design and Built Environment, Curtin University, Perth, WA 6845, Australia; \\ j.stephens@curtin.edu.au (J.S.); r.tiwari@curtin.edu.au (R.T.) \\ 2 High Institute of Engineering and Technology, El Behira 22699, Egypt \\ * Correspondence: f.hussein@postgrad.curtin.edu.au; Tel.: +61-469606078
}

Received: 2 September 2020; Accepted: 30 September 2020; Published: 2 October 2020

check for updates

\begin{abstract}
Historic urban landscapes (HULs) are composed of layers of imbedded tangible and intangible features such as cultural memories. As the collective memories of city inhabitants, cultural memories can affect elements of social sustainability such as health, well-being, community identity, place perception and social engagement. Utilising the popular Zanqit Alsitat (also known as 'Zanket el-Setat' or 'Zane't El-Settat'), the only remaining historical street market in Alexandria, Northern Egypt, this research proposes a theoretical model for recalling and continuity of cultural memory features in HULs, which can be used to achieve social sustainability. The research explored the site by applying a qualitative methodological approach through semi-structured in-person interviews in the study site, along with analysis of comments obtained from a research-purposed social media (Facebook) group. A qualitative data management software (NVivo12 programme) was utilised for interpretation and charting the features of stored cultural memories relating to this place. The study indicates that educing and maintaining the features of cultural memory in HULs contributes to social sustainability through its influence on the formation of place identity, sense of place, civic pride and quality of life. This framework for social sustainability in HULs can be applied by engaging social groups through participatory planning.
\end{abstract}

Keywords: historic urban landscapes; participatory planning; place identity; quality of life; sense of place; social sustainability

\section{Introduction}

Globally, urban transformation is affecting the identity of cities and the experience of residents, especially in historic cities. Historic urban landscapes (HULs) have been gathering increased attention since the 2011 recommended actions of the United Nations Educational, Scientific and Cultural Organization (UNESCO) that aimed to manage the deterioration of historic urban settings. The UNESCO led actions recommended a remedial plan for the social and cultural fragmentation that results from uncontrolled urban development in such settings [1]. These recommendations were inclusive in defining the HUL as 'the urban area understood as the outcome of a historic layering of cultural values and natural attributes, that extends beyond the idea of "ensemble" or "historic centre" to involve the wider urban context and its geographical setup' [2]. One of these values is 'memory', which is defined as our mental capacity to retain and revive events and to recall our previous experiences-abilities which help to preserve our past [3]. Memory can be individual or social (collective), or so called 'cultural memory'. Cultural memory is studied in various interdisciplinary sciences, including psychology, sociology, history and anthropology, but its potential contribution to 
urban development has rarely been recognised. It is an important aspect of urban landscapes such as cities where-as discussed in this paper-cultural memory is essential for successful place making and the maintenance of social and cultural identities.

Alexandria, the 'second capital' and main port of Egypt, has recently been experiencing an accelerated rate of urbanisation and industrialisation to meet the needs of its growing population. This has created urban, social and environmental threats to the city's HULs. The Zanqit Alsitat (also known as 'Zanket el Setat' or 'Zane't El-Settat') historical street market is one of the most important and memorable HULs in Alexandria. It is currently facing physical decay and environmental pollution, issues which are threatening the place attachment, memories, place image, usage and social interaction of its users [4].

Focusing on the HUL of Zanqit Alsitat, this research investigates the features of cultural memories that are present in HULs. It investigates further the active role of cultural memory reproduction essential for quality of life and well-being to drive social sustainability and sustainable development. In order to achieve this, the article outlines the definition and themes of social sustainability along with key features of cultural memory.

\subsection{Social Sustainability}

The concept of sustainability involves seeking equality and enhanced administration of our world's resources, and it includes a number of emerging dimensions such as cultural, economic, social, institutional, technological and environmental aspects [5]. Sustainable development is 'development that meets the current demands without challenging the ability of next generations right to sustain their specific needs' [6]. Sustainability comprises three dimensions: the environmental, social and economic dimensions [7]. However, within the sustainability discourse, policy makers have not prioritised these three dimensions equally. The environmental dimensions were the focus in the 1980s, while the economic dimensions dominated the sustainable development debate until the mid-1990s. The 'social' has only been part of the technologically dominated sustainability agenda since the late 1980s resulting in a limited amount of literature that focuses on social sustainability and its role in environmental debates [8]. Ezenberg and Jabareen explain early sustainability debates centred mainly on endangered species and ecosystems but soon extended to include urban settings. Urban social sustainability is described as 'the continuing ability of a city to act as a long term, viable setting for peoples' communication, interaction and cultural progress' [9].

Grießler argues that social sustainability approaches are not founded on theory rather than on the social implications of environmental political goals [10]. However, Polese and Stren offer a global definition of social sustainability with emphasis on urban environments. They focused on the social (civil society, cultural diversity and social integration) and economic dimensions of sustainability without forgetting the value of the physical context (e.g., public spaces, houses, design) within urban sustainability [11].

Bramley distinguishes two inclusive concepts as being central to social sustainability. The first is 'social equity', which is aligned to the domain of social justice and concerns the equal distribution of community resources, such as allowing fair attainment of jobs, accommodation and services. The second is 'sustainability of community', which deals with the viable continuity and functionality of the community as a collective organisation. Within their interrogation of the relationship of social sustainability to the concept of 'sustainability of community', they found that this depends on the inclusion of several features such as interchanges in the social networks, community participation, pride or sense of place, community stability and continuity of security (from crime) [12].

In the outcomes of a research programme on social sustainability funded by the European Investment Bank, Colantonio expands the understanding of the nature of social sustainability by noting that 'Social sustainability is founded on improvements in the thematic areas of the social realization of societies and individuals, spanning from building capacities and skills development to spatial and environmental inequalities. He defines social sustainability by explaining thirty-eight key theme areas 
(please see below) under four main categories: the social, socio-institutional, socio-economic and socio-environmental [13].

Colantonio's thirty-eight key theme areas of social sustainability are divided into four categories: (1) Social dimension includes access to resources, community needs, conflicts mitigation, cultural promotion, education, elderly and aging, enabling knowledge management (including access to e-knowledge), freedom, gender equity, happiness, health, identity of the community/civic pride, image transformation and neighbourhood perceptions, integration of newcomers and residents, leadership, justice and equality, leisure and sport facilities, less able people, population change, poverty eradication, quality of life, security and crime, skills development, social diversity and multiculturalism, well-being. (2) Socio-institutional dimension includes capacity building, participation and empowerment, trust, voluntary organisation and local networks (social capital). (3) Socio-economic dimension includes economic security, employment, informal activities/economy, partnership and collaboration. (4) Finally, socio-environmental dimension includes inclusive design, infrastructure, environmental health, housing, transport, spatial/environmental inequalities. [13]

Recently, the sequential analysis of social sustainability has shown a shift from appreciating only the tangible 'hard' themes towards the intangible 'softer' concepts within the sustainability debate. In this process, traditional themes, such as poverty alleviation, equity and livelihood, have been substituted by emerging themes- those that are less measurable and more intangible, such as identity, sense of place and the added-value of 'social networks' (see Table 1) [14,15]. Accordingly, some key areas of social sustainability are inter-related with cultural memory and have the potential to facilitate sustainable development. These include identity, sense of place and community engagement [15].

Table 1. Traditional and emerging key themes of social sustainability.

\begin{tabular}{cc}
\hline Traditional & Emerging \\
\hline Basic needs, including housing and environmental health & Identity, sense of place and culture \\
Education and skills & Health and safety \\
Employment & Well-being, happiness and quality of life \\
Equity & Demographic change (aging, migration and mobility) \\
Human rights and gender equality & Empowerment, participation and access \\
Poverty & Social capital \\
Social justice & Social mixing and cohesion \\
\hline
\end{tabular}

\subsection{Cultural Memory}

Cultural/collective memory is the act of recalling events that are related with objects, places and encountered by people in a social framework or between groups that experience these events [16]. Collective memory is reckoned to be a repository of culture, and sometimes this view leads to the term 'cultural memory' being used interchangeably [17]. Cultural memory (or collective memory) was parented for the first time into the literature by Maurice Halbwachs in his books The Social Frameworks of Memory (1992 and 1925) and On Collective Memory (1980 and 1950). His understanding of cultural memory was founded on a differentiation between individual and collective memory, and he described individual memory as 'personal' and 'autobiographical', while collective memory is 'social 'and 'historical' [18]. Following the introduction of the concept by Halbwachs, it was Pierre Nora who further studied spatial collective memory, and he was notably concerned with the geographical and built environment. He discussed how certain places can capture different emotions and embody national memories [19]. Further building on Halbwachs' contributions, the concept of 'urban memory' was founded by Aldo Rossi in his book (The Architecture of the City) and that allowed the concept of collective memory to be introduced into architecture and urban design. In this book, Aldo Rossi argues that preserving heritage sites is the equivalent of retaining people's cultural memories and protecting their national identities [15]. 
Christine Boyer added to this discussion in her book City of Collective Memory in which she explains that a city's architecture is what governs its collective expression, which carries the traces of the earlier architectural shapes, along with planning and monuments of the city. She explains that while the names of cities may not change, their physical elements are always transformable, being forgotten and modified to match new demands, or even vanish in the pursuit of different purposes. 'The demands and pressure of social reality always impact the material order of the city'. However, our collective and individual memories can inform the changes happening and help us to distinguish our city from others by recognising its streets, monuments, architectural forms and traces [3]. Paula Hamilton notes the importance of the physical aspects of an environment that trigger remembrance and emotions through processes that continually re- enchant city spaces. Echoing Halbwachs she says collective memory is 'a record of resemblances and similarities. That is kept viable by persistent reworking and transmission' [20]. Here, 'similarity' is a useful concept employed later in this paper to understand how tangible and intangible features of a place contributes to users' social image of place.

All these theorists point to the important link between cultural memory and memorable places in cities that evoke collective images and perceptions and shape the city's character and identity. Kevin Lynch also contributes to this link through his books What Time is This Place? and A Theory of a Good City Form in which he explains that the existence of an 'image of time' is important for users' psychic and mental health. In addition, his explanations point to the links existing between planning and psychosocial well-being (please see below) [21], and he states that the 'crucial function of planning is to feed psychological and social bonds to places by seeking after the values of community, continuity, health, well-functioning, security, warmth and balance' [22,23].

Psychosocial well-being is a condition that includes a full range of what is good for a person such as; participating in a meaningful social role; feeling happy and hopeful; living according to good values, as locally defined; having positive social relations and a supportive environment; coping with challenges through the use of appropriate life skills; and having security, protection, and access to quality services. [21]

Other scholars elaborate on how our encounters with past objects and places create a clear sense of the past and help to form personal identity and place identity [24,25]. Psychologists consider place identity to be the contribution of characteristics of place to one's self-identity [26]. Place identity is defined as 'the set of characteristics that enable the place's distinctiveness and continuity over time' [27]. Relph explains that the forming of place identity will vary based on the agreed individual or group image of the place [28]. Therefore, cultural memory acts as the central medium for constructing collective place identities and is therefore an essential factor in ensuring a meaningful place and a rich civil society [29]. Cultural memory has the capacity to improve place meanings and identity, create a bridge between memories and places, provide a clear image of the past and establish a sense of place and belonging [30].

Sense of place is a broad concept that has been conceptualised by a number of scholars (e.g., Relph [28]; Tuan [24]; Steele [31]; Eyles [32]; Jackson [33] and Hay [34]). It is defined as the complex bundle of meanings, symbols and qualities that an individual or a group could relate with a particular region [35]. David Hummon added to the concept by explaining that sense of place is unavoidably dualistic in nature, and it involves an interpretive perspective and an emotional reaction towards the environment. Three main components are involved in sense of place, these are: physical setting, activity and meaning [36]. Williams and Stewart elaborate on sense of place further as being a comprehensive concept that pictures all the ties that people relate with places, for instance emotional bonds; realized meanings, memorable events, symbols and values; the qualities of the place; and awareness of the historical and cultural importance of the place [37]. Eisenhauer mentions that sense of place includes place interactions of families or friends, their traditions, and the memories linked with the people of the place [35,38]. Thus, memories and local identities can accurately reflect how people feel joy in, and how they are attached to, their urban environments [39]. Thus, it could be 
argued that cultural memory can impact social sustainability and facilitate sustainable development through contributing to key theme areas such as public place images of time, community perceptions, community identity, civic pride, sense of place and quality of life.

This article is the third of an integrated site analyses aiming at interrogating the contribution of cultural memory towards attaining psychosocial well-being in HULs. In our research, we explored three "distinct" case sites in Alexandria, Egypt—where each of the three sites were parented with its complexity and rich features that enabled us to explore various research objectives. Within our previous research, the case of Orabi Square, was utilized to contrast the site's historical versus current conditions in concert with the concept of place experience. This study demonstrated that cultural memory has an active role in shaping the emotional attachment to place, and contributes to a sense of place that promotes a rich quality of life and place experience [40]. Our recent publication on the demolished theatre 'Masrah Al Salam', presented a rich case to explore the importance given to cultural memory by the people inhabiting the study area. The case of the demolished theatre 'Masrah Al Salam' revealed the importance of cultural memory linked to elements such as iconic heritage buildings that contribute to a sense of place and enhance the urban environments identity [41].

Building on our previous work, the current study aims to understand how maintaining the elements that embody cultural memory in HULs contributes to the establishment of place identity, sense of place and civic pride leading to quality of life. In addition, we explore the capacity of cultural memory to contribute to the bigger image of urban management and sustainable development by driving social sustainability through the formation of place identity, sense of place, civic pride leading to quality of life.

\section{Materials and Methods}

\subsection{Study Setting}

Alexandria was established c 322 BCE and named after its founder, Alexander the Great. Besides being the capital of Egypt and an important regional centre, it became the scientific and intellectual focus of the Greek and Roman Empires for many centuries [4]. During Arab rule (from 642 AD) Alexandria's prosperity withered after the capital of Egypt was moved to Cairo in 969 AD. The decline continued, accelerating in the 14th century. The population of the city shrank and became centred near the Heptastadion (Figure 1). The area, formerly known as the Turkish Town, later formed the city centre (El-Mansheya) [42].

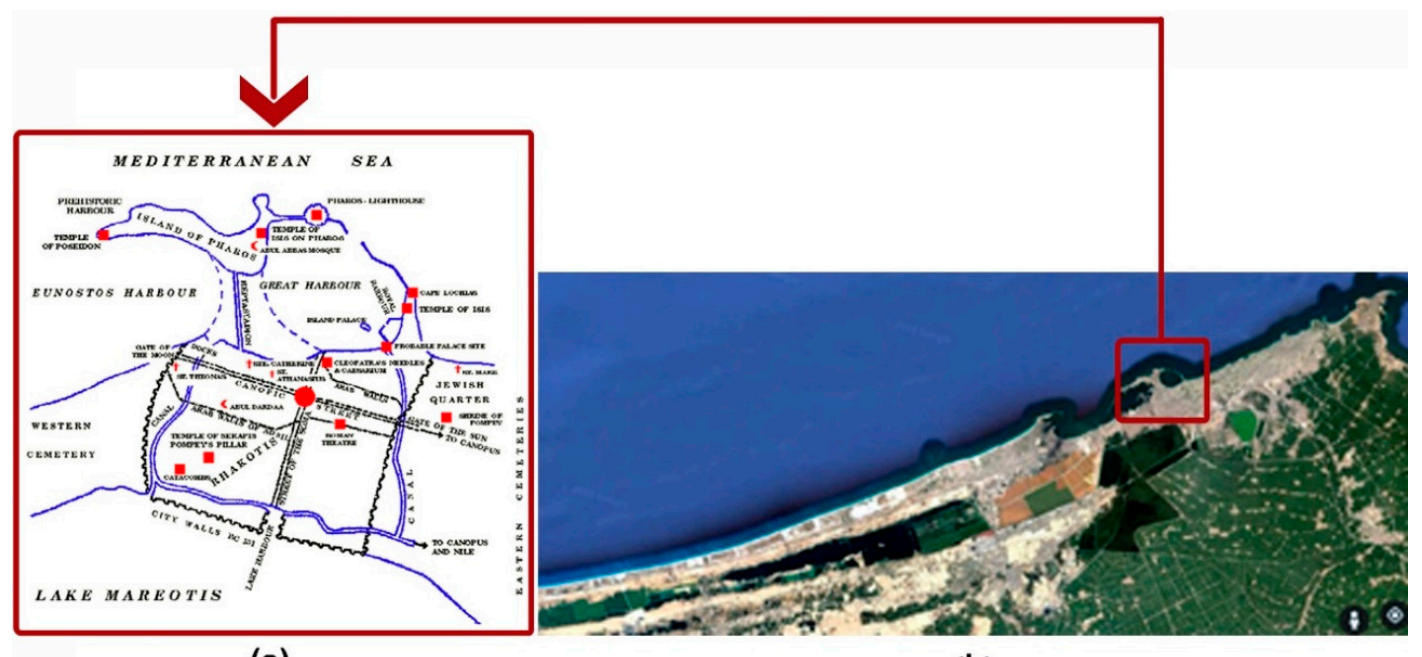

(a)

(b)

Figure 1. The city of Alexandria (a) Old map of Alexandria demonstrating the ancient Heptastadion [42] (b) The modern Alexandria, related to the ancient Heptastadion (pointed to in the red square). Source: Google Earth. 
Nowadays, Alexandria is the second largest city and the main harbour of Egypt. It is spread over an area of $2679 \mathrm{~km}^{2}$ has 5.2 million inhabitants (2018 census) [43]. Alexandria city was selected to conduct this study because it is facing an accelerated urban expansion that has inflicted developmental pressure on its HULs, which ultimately threating their usefulness or survival. The selected study site is the HUL Zanqit Alsitat street market, described as follows.

Zanqit Alsitat is located in the El Mansheya district (Figure 2) and is the most important and celebrated old market in Alexandria. There is a debate over its age. Some sources say that it goes back to the Napoléon French campaign in Egypt as it was constructed on the remains of the French soldiers' horse stables. However, most agree that it dates from the Ottoman period and the Mohamed Ali era in the 18th century as it is established in the historic part of Alexandria called the Turkish Town. The suq (market) is the only remaining Ottoman suq in Alexandria [44]. It has changed little in its design since it was constructed, except in the elevation of its shops [45]. It is an area of alleys and one or two-storey houses, and it still retains its character of narrow streets with many small shops. The suq appears as a maze since you can enter and leave it from many places.

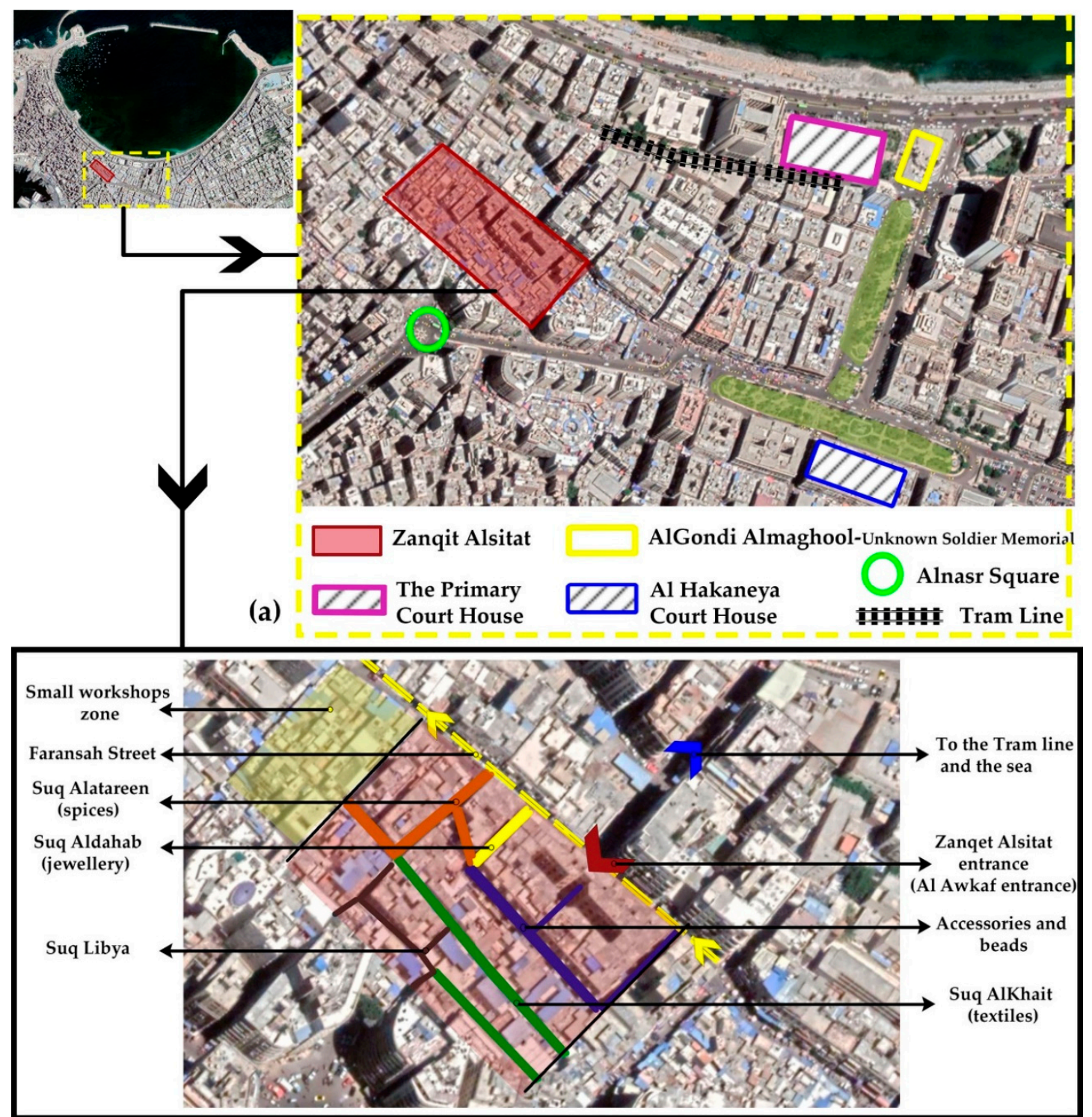

(b)

Figure 2. Zanqit Alsitat satellite maps. (a) Zanqit Alsitat location in the El-Mansheya district with landmarks highlighted. (b) Zanqit Alsitat market with major activity zones identified. Source: Google Earth modified by researchers. 
This site was chosen due to its public and cultural importance of being one of the very few remaining parts of what used to be the Turkish Town. The market is busy and vibrant on a daily basis and it is currently facing physical decay and environmental pollution which puts this important place at physical risk and ultimately at risk of losing the social and cultural benefits that it generates. However, it has not undergone any formal renovations or had any management plans so that unsympathetic physical intervention has been minimal. This makes it an ideal site to investigate the potential for maintaining cultural memories and to be utilised as a catalyst for social sustainability and sustainable development in future plans.

\subsection{Data Gathering and Analytics}

We used a qualitative approach to study the features of maintaining cultural memory in HULs, in order to attain social sustainability as a theoretical model for sustainable development. The data gathering was split into two stages: a stage of a desk study, followed by the stage of in-field data gathering. The desk study stage was initiated to base the theoretical framework for this study through a critical review of literature. In this first stage, we aimed to study the inter-relationships between these main concepts, such as HUL, cultural memory, place identity, sense of place and social sustainability. From this, the conceptual framework of the study was created, and the interview questions were designed.

In the second stage of the study, in-person semi-structured interviews were conducted with users of the Zanqit Alsitat historical street market. The questions of this interview were first tested in a pilot project to check the validity of the questions and the time needed to conclude the interview. The pilot interviews revealed the need for some re-wording for clarity. Finally, the main research concepts were tailored into an interview of 21 questions, such as:

- Can you sketch your mental image (cognitive map) of the market?

- What do you feel when you are at this place? Why?

- What are the celebrations, events or traditions that usually takes place in this site?

- What are the stories or legends that are linked to Zanqit Alsitat/do they affect your stay?

- In your opinion, what makes this site unique (in one sentence)?

The research included 12 interviews, with the sample size guided by Morse who argues that researchers adopting the qualitative research methodology should have at least five subjects to validate the nature of an experience [46].

The participants in this study are clustered in two groups, static users (those who have constant engagement with the place such as shop owners, shopkeepers, vendors, office workers and residents) and mobile users (those who are not engaging daily with the place, this group of users include visitors and shoppers). Table 2 summarises key data of the participants. Each in-person interview took around three-quarters of an hour. Most of the interviewees in this study cooperated well and answered all of the 21 question; however, some (four participants) declared reservation on answering just one of the questions. This was the one was asking for a mental-map sketch; some of the interviewees did not feel comfortable in delivering their answers by drawing. Hence, we collected eight mental-maps out of the anticipated twelve. All the interviews were conducted during the time-frame July to August 2018, and all the participants were asked if their interviews could be recorded and transcribed. In addition, they were given an informed consent form with the guarantee that they would not be identified in the future.

Table 2. Participants at the Zanqet Alsitat historical market divided into age and gender. Source: F. Hussein.

\begin{tabular}{cccc}
\hline Age & Women & Men & Total (No.) \\
\hline $16-34$ & 2 & 1 & 3 \\
$35-49$ & 2 & 2 & 4 \\
$50-65$ & 2 & 3 & 5 \\
\hline
\end{tabular}


The second stage of data collection relied on social media as a potential tool for gathering opinions related to qualitative research domains $[47,48]$. For the purpose of this study, we set up a new Facebook group (Alexandria's Spirit). The social media group was utilised for sampling Alexandrian participants' comments and opinions concerning the study site. This approach proved to be a useful source of sharing opinions without the stress that accompanies traditional face-to-face interviewing methods [49]. In compliance with the Human Ethics approval (Curtin University, Australia-Permit No. HRE 2018/0698), the Facebook group participants (92 members to date) were informed and consented regarding the study objective. They also consented that the status of the group will be open to the public and that their data (profile name and account) would be publicly available on the internet.

The Facebook group can be accessed at: (https://www.facebook.com/groups/1801504963488546/). The Facebook group hosts old and modern photos of Zanqit Alsitat and visitors to the page were requested to post and exchange comments, narratives or information. Thirty-six comments were sourced from the Facebook group that relate to Zanqit Alsitat historical street market, and these were all extracted into document files for further analysis.

The participants' collective memory of the physical components of the market (the streets and lanes) in Zanqit Alsitat were analysed regarding the form and features in the sketched mental maps, including the names, content, accuracy of roads, streets, alleys and landmarks together with answers to the in-depth interview questions [50].

For the data analysis, the research used the qualitative triangulation method by cross-referencing observations noted through field visits with the face-to-face interviews to achieve a deeper insight [51]. The contents collected from the Facebook group were analysed qualitatively to elaborate on the participants' memories, feelings and sense of place [52]. Coding and data management was done using the NVivo 12 software (QSR International, Burlington, MA, USA). The key investigated concepts were then divided into modules to generate structured tree nodes representing the research themes. All the interview participants' answers and comments from the Facebook group were extracted, and then coded within the nodes and sub-nodes (Figure 3) to interrogate and understand their relationships.

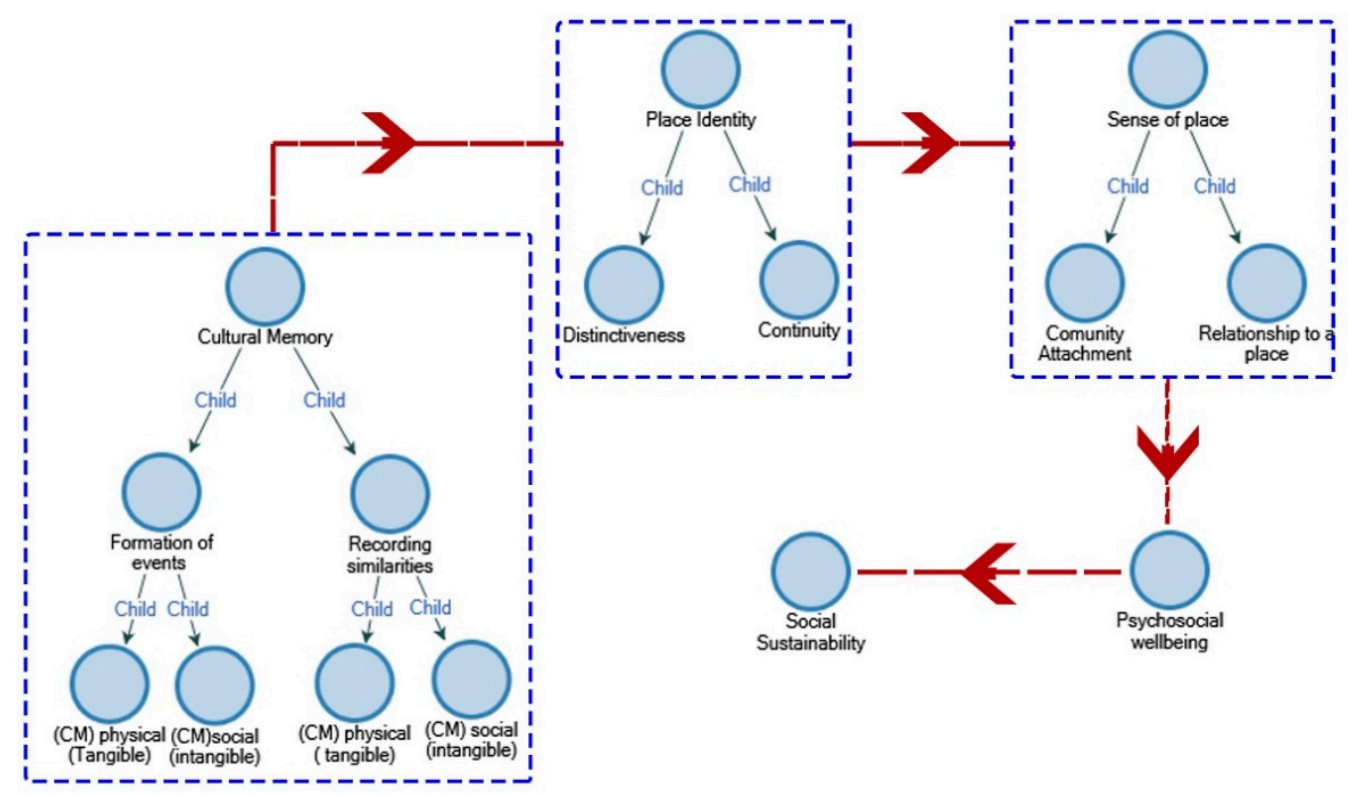

Figure 3. The diagram illustrates the research themes and their relation to the coding process using the NVivo12 programme. The themes are shown in terms of node-'nodes and sub-nodes' in the thematic coding and analysis process. This diagram is an extract from the NVivo12 programme. Source: F. Hussein. 


\section{Results}

The qualitative content analysis for the on-site interviews and the Facebook contributions of Zanqit Alsitat historical street market revealed the processes of maintaining cultural memories in HULs in relation to its contribution to place identity, sense of place and social engagement to drive social sustainability-the following findings were extracted:

\subsection{Cultural Memories Rooted in Place (Formation of Events and Recording Similarities)}

The interviewees recalled and appreciated the importance of cultural memories that were rooted in Zanqit Alsitat and shaped through the tangible and intangible dimensions of the site.

\subsubsection{Formation of Events}

The interviewees and the Facebook participants indicated 100\% agreement on the contribution of the place both tangibly and intangibly to their stored memories, as it was the context for some of their important lived events, traditions, celebrations and social interactions. Without the place physical experience, memories of important aspects of their life would be lost-culture would be lost.

All 12 interviewees and the Facebook comments mentioned how the site was, for them, related to celebrations, mainly Ramadan and Eid, whether buying Ramadan toys and lanterns for the children or just through enjoying the whole area with its street decorations-activities and elements that have distinguished the place for many years (Figure 4). They also recalled wedding preparations, such as buying wedding rings, textiles and even cookware and wedding invitations. For them, every time they visit the suq, they recall memories of happiness and joy that are sustained across many generations.

The whole area has a special taste at Ramadan and Eid as people decorate the streets and hang lights. It's in our culture, all the celebrations are connected to 'Zanqit Alsitat': people buying a lot of gifts at these occasions which make the suq liveable and cheerful. Male interviewee, 73 years (sample of analysed answers)

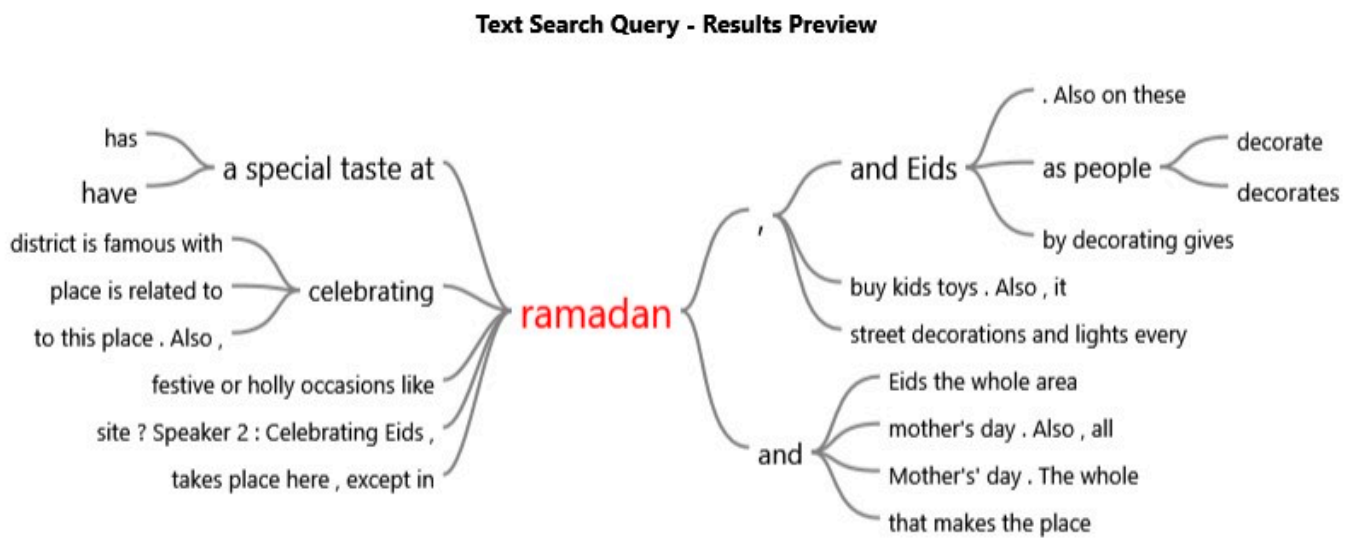

Figure 4. Preview of an NVivo12 output for text query function-the figure shows the common reporting relationships associated with the word Ramadan. Source: F. Hussein.

\subsubsection{Recording Similarities}

The site contained tangible (physical) and intangible features that were recorded similarly in users' memories. These recorded similarities were reflected through the interviewees' drawn mind-maps and their narratives. The interviewees' mind-map drawings (Figure 5) contained Kevin Lynch's main five elements (path, edge, district, node and landmark), which form and describe a place image [53]. The physical environment of the suq was very important in preserving the participants' memories and the site's image. The built environment image for Zanqit Alsitat was represented by sketching, mainly of edges, districts, nodes and landmarks. The paths were harder for the participants to draw as they noted that it was like a maze (see Table 3). 
The mental-maps showed that all the interviewees agreed that the Al Awkaf entrance, the suq's main entrance from Faransah Street, represented the main node, and the start for their shopping adventure. They also agreed that Faransah Street was the main edge of the place and its name was important as it reflected the place's old history. Most of the interviewees (9 out of 12) mentioned the large number of historical monuments and buildings of beautiful architectural character, such as the Al Hakaneyah Court House and the Al Shorbagy Mosque, that also served as landmarks for the whole district.

Interviewee narratives also mentioned the intangible, in terms of the differing senses used in capturing and recalling the memories. They mentioned the smell of the delicious, but inexpensive, sandwiches in Faransah Street sold by the street-food vendors in front the Al Awkaf entrance. Additionally, the sea breeze reminded them about the proximity of the seafront even though it could not be seen from the suq. The colourful textiles and beads that surrounded the place also contributed to the users' visual images and memories of the site.

In addition, all narratives mentioned the famous Raya and Skeena story-the two criminal sisters who used to kidnap women from the market and kill them for their gold. Surprisingly, the story didn't negatively affect the peoples' experience of the place, on the contrary, they thought it made the place more famous and attractive- even for non-Alexandrians to come and explore.

Table 3. Kevin Lynch's five elements of a city image identified in the participants' sketched mental-maps Source: F. Hussein.

\begin{tabular}{|c|c|c|}
\hline Element & Description/Definition & Main Remembered/Sketched Element \\
\hline Edge & $\begin{array}{l}\text { Linear elements that form a boundary } \\
\text { between two parts }\end{array}$ & $\begin{array}{l}\text { - Faransah Street (Appendix A: Figure A1a). } \\
\text { - The Tram line and the sea promenade }\end{array}$ \\
\hline District & $\begin{array}{l}\text { Medium-to-Large areas of the city, where } \\
\text { the eyewitness mentally gets inside of and } \\
\text { is recognised with having some common } \\
\text { identifiable characteristics }\end{array}$ & - El Mansheya district zone \\
\hline Node & $\begin{array}{l}\text { 'Focus of citizens' routes with dual } \\
\text { characteristics of connecting } \\
\text { and concentrating }\end{array}$ & $\begin{array}{l}\text { - Zanqet Alsitat main entrance (Al Awkaf entrance) } \\
\text { (Appendix A: Figure A1b). } \\
\text { - The street food kiosk (near the entrance) } \\
\text { (Appendix A: Figure A1c) }\end{array}$ \\
\hline Landmark & $\begin{array}{l}\text { A reference point, always used as } \\
\text { an indent. }\end{array}$ & $\begin{array}{l}\text { - } \quad \text { Al Hakaneya Court house (Appendix A: } \\
\text { Figure A1d). } \\
\text { - The Primary Court House (Appendix A: } \\
\text { Figure A1e). } \\
\text { - } \quad \text { Orabi Square (Appendix A: Figure A1f). } \\
\text { - Al Shorbagi Mosque (Appendix A: Figure A1g). }\end{array}$ \\
\hline Path & $\begin{array}{l}\text { Channels for daily activities such as } \\
\text { walkways and motor ways. }\end{array}$ & $\begin{array}{l}\text { The inside suq alleys were hard to remember in detail. } \\
\text { However, people sketched the main zones according to } \\
\text { their activities. } \\
\text { - } \quad \text { Suq AL Khait (textiles) (Appendix A: Figure A1h. } \\
\text { - } \quad \text { Suq Al Atareen (spices) (Appendix A: Figure A1i). } \\
\text { - Suq Aldahab (jewellery) (Appendix A: Figure A1j). } \\
\text { - Suq Al kharaz (beads and accessories) (Appendix A: } \\
\quad \text { Figure A1k). }\end{array}$ \\
\hline
\end{tabular}




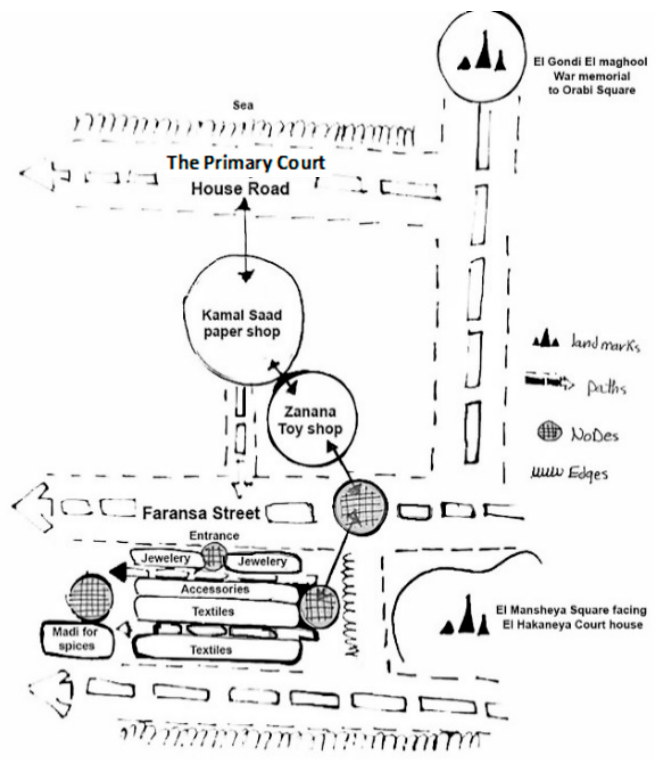

(a)

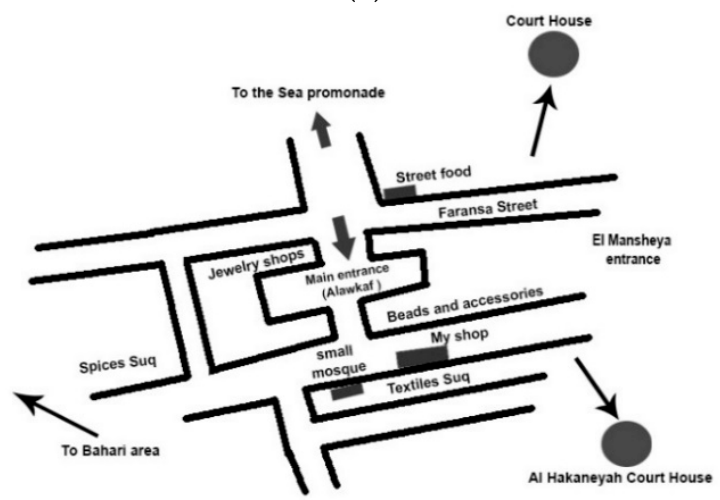

(c)

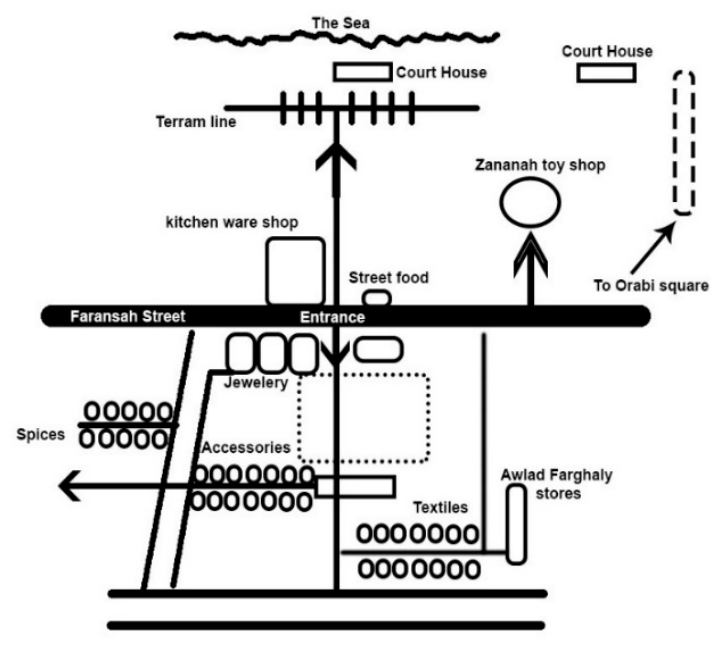

(b)

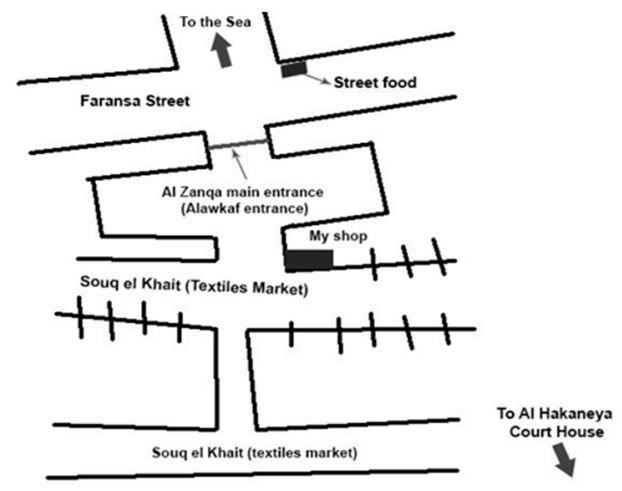

(d)

Figure 5. Sample of the interviewees' sketched mental maps. (a) 28 years old female mobile user mental map. (b) 35 years old female mobile user mental map. (c) 54 years old male static user mental map. (d) 48 years old male static user mental map. Note: To improve the visual effect of figures, all drafts were refined in graphics software based on the interviewees' hand-drawn sketches. Source: F. Hussein.

The maps showed that the mobile users have a holistic and collective image of the place, while static users have a localised and personal image. As such, the mobile users described the suq with its surroundings, while the static users were more focused on their shops and the inner details of the suq.

\subsection{Place Identity (Continuity and Distinctiveness)}

\subsubsection{Continuity}

All participants said that Zanqit Alsitat engendered confidence in the continuity of their city's well-known features, as the main features of the suq had not changed over time. However, informal renovations done by the shop owners, such as changing the old basalt flooring blocks and the shops' elevations, made them worry about the place losing its visual identity eventually as this would affect their feelings of continuity and certainty. 
Luckily the suq didn't undergo changes in its overall planning, but the suq floorings used to be of the heritage basalt blocks and are now changed to be like contemporary pavement tiles. Also, all the shops used to have beautiful (Fer Forges) doors and all those were changed as well as some changes in shops' activities or owners. Male interviewee, 54 years (sample of analysed comments)

\subsubsection{Distinctiveness}

All participants agreed that the suq was famous and unique as it is the only one of its type in Alexandria. In addition, it is well-known that you can find items you cannot find in the large shopping malls. It is crowded, but that is a part of the experience, and people understand that and can accommodate it. They are happy with the crowd as it is part of the experience and it means that the trading process is going well.

One of the most beautiful places that I love, in which everything you imagine can be found in these compact crowded alleys. I always used to go with friends to buy lovely gifts such as embroidered textiles, accessories and beads, hand-made sarma, fabrics of all kinds, gemstones, silver, golds and perfumes. Also, you can find the traditional folkloric Alexandrian ladies' custom 'Melaya Laff and burko' and the traditional fishermen custom as well. Really a charming nostalgic and unique place. Facebook comment by Elhamed Lellah (sample of analysed comments)

All the interview comments described the significant character of the suq with its simplicity and authentic taste, which brings Alexandria's famous historical image to their minds.

The suq is so unique, you can enjoy the old soul of Alexandria that you hear about in grandparents' stories and watch in old movies. It's a shopping experience with a heritage flavour, which is so enjoyable. Female interviewee, 28 years (sample of analysed comments)

\subsection{The Valued History in the Site}

All participants regarded Zanqit Alsitat as very rich in terms of its historical background as it is located within the old Alexandria zone. All the interviews reflected that users had sufficient historical information about the suq's origins, its formation and naming. Additionally, they appreciated the importance and effect of knowing this history on their experience of the site.

I heard that this area used to be a horse stable for the French campaign soldiers in Alexandria, then after a long time (during the Mohamed Ali era), the Moroccan Jewish traders came here and started the suq. The suq was special and famous for being metropolitan, (it has Moroccan, Tunisian, Italian and Armenian traders and goods) and that is what gives it its famous reputation. Male interviewee, 48 years (sample of analysed comments)

Participants said that knowing this is a historical site makes them proud that it still exists and, at the same time they feel nostalgic for the old days. In addition, they mentioned that being in a historic place made them feel responsible for protecting the place and its character.

\subsection{Sense of Place (Relationship to a Place and Community Attachment)}

3.4.1. Relationship to a Place "Biographical, Spiritual, Ideological, Narrative, Commodified and Dependent Bonds"

The study participants pointed to different relationships with Zanqit Alsitat that affect their experience toward the site and their sense of place. Four types of relationships with site have been expressed by the interviewees. All static and mobile interviewees and Facebook participants primarily expressed a spiritual bond: the emotional feeling of a sense of belonging that is simply felt rather than created; a commodified bond: choosing a place according to its desirable features; and a narrative bond: learning about a place through its stories [54]. 
I don't know exactly why I'm attached to this place, I just love being here, sometimes I just come only to have a walk through the streets, even when I don't need to buy anything. Just watching the small shops and local goods makes me feel nostalgic.. Facebook comment by SaRa Medhat Saad (sample of analysed comments)

Finally, biographical bonds were expressed by most of the static users (4 out of 6 participants) who expressed that they feel tied to the suq because they grow-up in El-Mansheya district, had lived there and had continued in their family business.

I feel so much bonded to this place even more than home maybe because I'm using this place for about 30 years now. I have been raised in this district, this shop is a family business and I am the third generation. Zanqit Alsitat with all its shops is my soul. Male interviewee, 55 years (sample of analysed comments)

\subsubsection{Community Attachment "Rootedness, Place Alienation, Relativity and Placelessness"}

All participants agreed about being completely rooted to the site: having a strong attachment, identification and involvement within the site's community. They mentioned their positive assessment and confidence about using the site and their expectation that they would continue in their future attachment to the site. However, 10 out of 12 interviewees along with all Facebook commenters expressed their concerns about losing their feelings of rootedness towards the site. This is because of the informal renovations done by the shop owners, such as changing the activities of some shops or even the types of goods sold. They also expressed their concerns about physical changes, such as changing the old basalt block flooring and changing the shops' elevations, which can change the spirit of the site.

For me, Zanqit Alsitat represents the spirit of old Alexandria and my childhood memories when I took a shortcut on my way to school and speeded up by using its alleys in the early morning when the suq was still empty. Its distinctive floor tiles and the narrow, covered paths between the short buildings and the smells still carry the remnants of old intimate times and of memories with my friends in the early mornings during school time and among its markets in the summer. The lanes still exist, but the significant goods (the perfume market, the jewellery, threads, embroideries and beads) have started to change since the old days, and now most of the things are 'made in China', which is so sad! Dr Iman Elbawab, 57 years, Facebook comment (sample of analysed comments)

\subsection{Social Engagement and Participation}

Nine out of 12 interviewees, together with all of the Facebook comments, reflected the feelings of responsibility that the users have towards the place. They all have concerns about the type of developments and changes that could happen to the suq without consideration for their opinions and needs. In this context, they mentioned the previous government's intentions for massive transformation during the time of President Muhammad Anwar el-Sadat (1970-1981), which included removing part of the suq to create a traffic road linking Faransah street to Alnasr Square. This was cancelled after the shop owners protested angrily for days.

I always remember the time of President el Sadat when there was a project idea for removing the entire market, but they stopped because of the shop owners protesting. This incident made me feel responsible for this place; I saw how important it is for me and for all the Alexandrians and the tourists as well. So, if there will be any development, of course I would like to participate because any change will affect the place and will therefore affect me as well. Male interviewee, 55 years (sample of analysed comments)

However, a few interviewees (3 out of 12) mentioned that they didn't care to participate in any future plans as they believed that their word did not possess any power to bring about change. 
I don't care about sharing my opinion and vision for the market, because the government will apply its plans anyway, without caring about our emotions, opinions or thoughts. Female interviewee, 50 years (sample of analysed comments)

\section{Discussion}

This study explores the elements that maintain cultural memories in HULs and could be used as a tool for driving social sustainability in future urban development plans for Zanqit Alsitat street market. The present study indicates that people appreciate the significance of recalling their memories in the formation of their HUL mental images. People also regarded the site's stored memories and history as an important driver for creating place identity and a sense of place that is reflected in their place experience and quality of life. The findings indicate that having a series of lived events and recording similarities are crucial for recalling and reproducing the tangible and intangible dimensions of cultural memories.

The suq is inhabited by social memories of Ramadan and Eid, of bridal celebrations and of joy, which were all so valuable as contributor to the site experiences and as reflected by participants in this study. This result matches the definition of cultural memory by Ardakani and Oloonabadi as 'a series of events remembered by a group of people who share it and involve themselves in shaping it' [55]. The participants reflected their perceptions of physical similarities such as edges, nodes and landmarks as well as intangible similarities such as narratives and other spatial expressions (e.g., smells and other senses). These similarities were significant for the formation of the participants' site cognitive image. This finding complies with Jones' argument that memory is expressed through texts, discourse and through visual-tangible materials [56]. Kansteiner explains that 'cultural memory comprises that body of reusable texts, images, rituals specific to each society in each epoch, whose cultivation serves to stabilize and convey that society's self-image,' illustrating how recording similarities contributes to the participants' social image of place [57].

The results also show that cultural memory contributes to place identification through protecting the site identifiers (e.g., landmarks or monumental buildings) that promote feelings of continuity and distinctiveness. This complies with Lynch's argument that people will form clear and accurate images of their places if the city-scape has a clear and identifiable physical form and the function and they will position themselves according to parks, edges, nodes and landmarks [53]. Participants' comments showed that the uniqueness and continuity of this site as being 'one of a kind' in Alexandria and the fact that it had not experienced any major planning transformation, created feelings of certainty and enjoyment that protected the place identity and experience. This supports Anton and Lawrence's understanding about sites possessing place identity and suggests that places that are more likely to be assimilated into the identity structure are those capable of making us feel unique, in charge, satisfied about ourselves and are aligned with our subjective realisation of who we are [58].

It was noticeable that all the participants were completely aware of the suq's historical background: Starting with the Napoléonic French campaign, the soldiers' horse stables had given the suq's main edge its name (Faransah Street), and the later existence of the Turkish Town was reflected in the urban fabric (the narrow alleys), while stories about the crimes of Raya and Skeena were recalled. This awareness of site history led to a repetition of the cultural memories rooted in this HUL and created collective feelings of responsibility and civic pride. This relationship between historical value and cultural memory agrees with Hoteit's argument that 'collective memory consists of the valuable landmarks in nation's history, it is these landmarks that are capable of advancing the sense of belonging at national level, as well as affecting the current and future lives of the community' [59].

The results indicate that cultural memory, place attachment, and the historical value of place, altogether, adds to a sense of place through forming relationship towards a place and a community attachment. This result agrees with Williams and Stewart explanation that sense of place is an appreciation of historical, cultural and spatial context that forms values, meanings and social 
interactions [37] and also with the argument of Cross concerning the components of sense of place as being the relationship to a place and community attachment [54].

The study findings indicate that users related differently to the suq and expressed various types of bonds to the site, for example the spiritual, commodified and narrative bonds, experienced by all users, while the static users mainly experienced biographical ties. These bonds added to their site identification and founded the base for immense emotions of rootedness in relation to the suq. This complies with Williams and Stewart contribution when they defined sense of place as the emotional bonds that people form with their places [37]. In addition, it points to the relation between sense of place and well-being as the stronger the bonds and the sense of belonging that people acquire towards a place the more well-being they will experience in that place [60]. However, the results also showed that the informal renovations and changes in some activities of the shop owners were threatening to the present feelings of rootedness and affected the sense of place of the whole suq, and if neglected, might lead to 'placelessness' in the future. This is the experience of place that Relph describes as happening "when places are deprived of their "unique" attributes, they become common, and such impact will undermine place identity' [28].

The findings reflect that cultural memory, with its contribution to place identity and sense of place, creates a feeling of responsibility towards a site. This is why some authors regard cultural memory to be a 'nationalist memory', that depicts the geography of belonging, an identity that is inseparable from a specific landscape [61].

All the participants had the feeling that the suq needs a preservation plan as it forms a part of their identity and civic pride. In addition, they showed their willingness to participate and to engage socially through incorporating their own memories, opinions and thoughts into any future urban development plan. The participants' ideas of participation match the concept of participatory planning, which seeks a transformation of power and social relations by shifting the focus away from the dominant planners' professional knowledge to the local community's emotions, opinions and knowledge [62].

In this context, the applied outcome of this work is to shape a theoretical model (Figure 6) for urban designers, city planners and administrators, demonstrating the importance of using cultural memory as a driving force in social sustainability through its contribution to place identity, community attachment, social pride, sense of place and well-being.

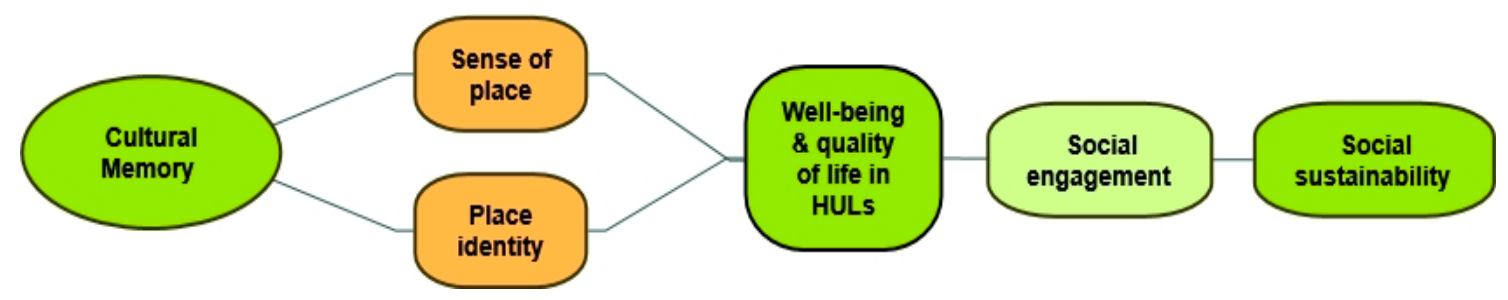

Figure 6. The proposed theoretical model used in the research and as executed using the NVivo12 programme. Source: F. Hussein.

\section{Conclusions}

This study explored a practical approach to understand how recalling and maintaining cultural memories embedded in HULs can contribute to social sustainability through a proposed theoretical model. The findings of this research have potential implications for the Zanqit Alsitat historical street market. Elements and concepts of cultural memory in relation to social sustainability were discussed in a rational process.

This research revealed how cultural memory consisting of inhabitants' past shared memories and valued histories has the capacity to create place identity and sense of place and to enhance place experience. In addition, it pointed out that the physical deterioration or deformation of the HULs is threating experience of the site as a context for events and stored memories. Which may result in the feeling of placelessness, affecting sense of place and provoking the sentiments of loss and sadness. 
Furthermore, it explained how the contribution of cultural memory to place identity and sense of place could facilitate sustainable development by reinforcing social networks and community participation, improving community identity and civic pride and increasing psychic health—as key theme areas for social sustainability.

Consequently, it is recommended that national urban planning authorities, urban designers and planners to recognise HULs as repositories of cultural memories and to ensure that their development and management reflect historical values by recalling and memorialising the activities and events that occurred there. It is highly recommended that these acts involve the representation of cultural memories together with conservation of historical physical fabric. This could happen through participatory planning, where the government would need to engage with the community and allocate sufficient time for realistic data gathering, making it possible to consider the cultural memories, emotions and opinions when dealing with HULs. Social groups could be more involved in participatory planning by conducting in-person interviews with static and mobile users of the site of interest. Such approach will cater for the identification of the memories that they want to preserve and sustain for next generations in order to create social cohesion and protect site identity, site experience and sense of place. Nonetheless, this is recommended to happen hand-in-hand with local community trust that their opinions-after practical considerations-will be recognised and acted upon.

To conclude, through the proposed framework of this research, cultural memory can work as an agent linking generations with the places of important events so that the old, current and foreseen mental dimensions of the people connected to the HULs can stay related. In this context, sustaining cultural and physical heritage for future generations is important and should be approached with the same acknowledgement that present generations have for mainstream sustainability and sustainable development.

Author Contributions: Conceptualization, F.H. and R.T.; Formal analysis, F.H.; Investigation, F.H.; Methodology, F.H.; Resources, J.S. and R.T.; Software, F.H.; Supervision, J.S. and R.T.; Visualization, F.H.; Writing —original draft, F.H.; Writing - review \& editing, F.H., J.S. and R.T.. All authors have read and agreed to the published version of the manuscript.

Funding: This research received no external funding.

Acknowledgments: The author acknowledges the support given from Amma Buckley, a Senior Research Fellow at Curtin University, Australia, for her guidance and advice while learning and using the NVivo12 qualitative analysis program for completing this study.

Conflicts of Interest: The authors declare no conflict of interest.

Ethics Approval: All subjects gave their informed consent for inclusion before they participated in the study. The study was conducted in accordance with the Declaration of Helsinki, and the protocol was approved by the Human Research Ethics Committee of Curtin University, Australia. (HRE2018-0698). 


\section{Appendix A}

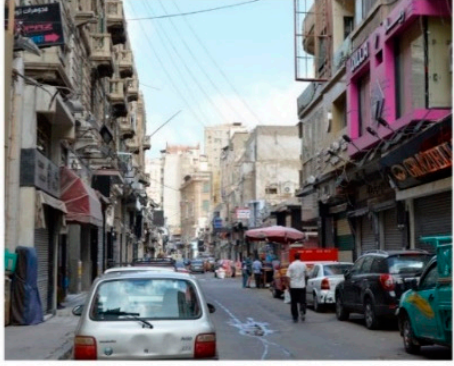

(a)

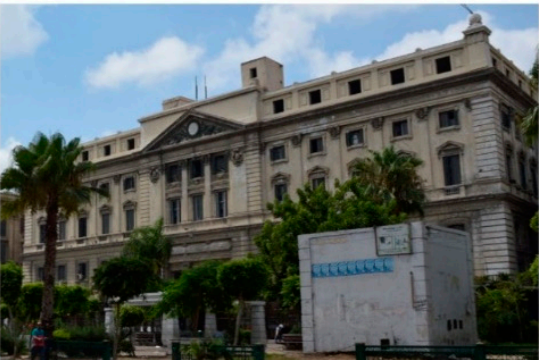

(d)

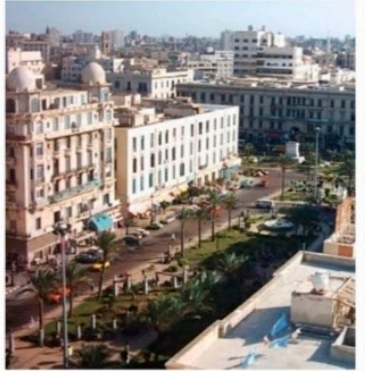

(f)

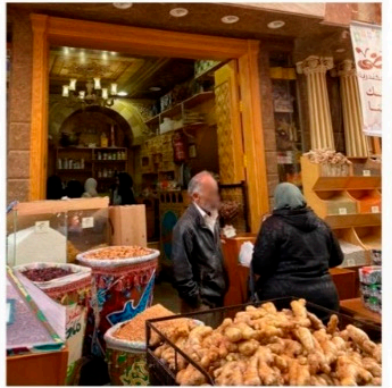

(i)

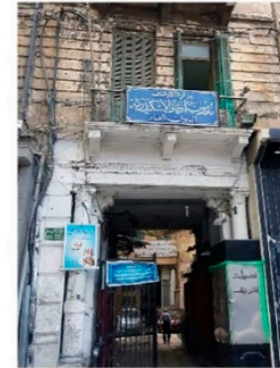

(b)

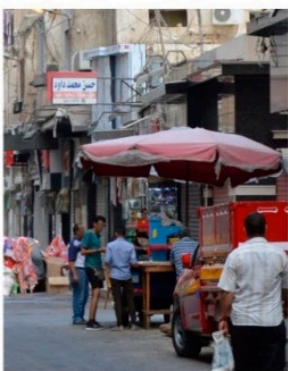

(c)

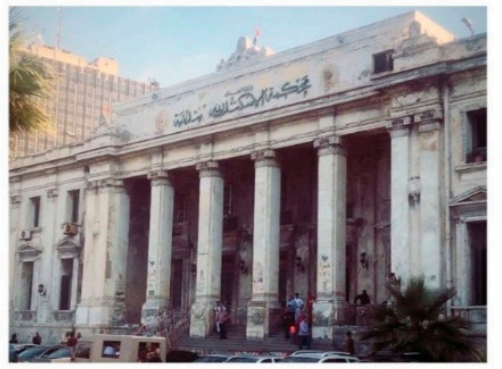

(e)

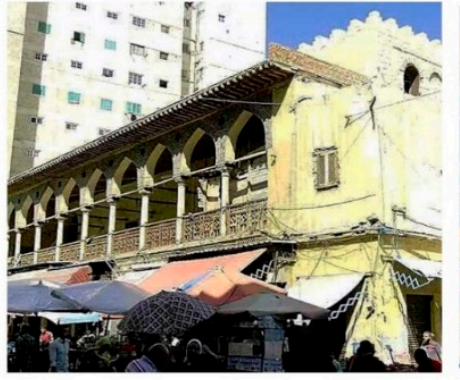

(g)

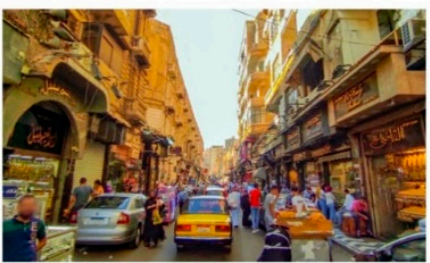

(j)

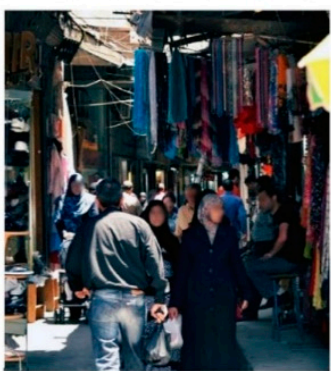

(h)

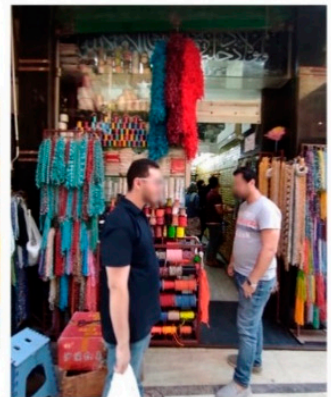

(k)

Figure A1. Pictures that Illustrate Kevin Lynch's Five Elements of the City Image Found in the Participants' Sketched Mental-Maps. (a) Faransah Street, (b) Zanqet Alsitat main entrance (Al Awkaf entrance), (c) The street food kiosk, (d) Al Hakaneya Court house, (e) The Primary Court House, (f) Orabi Square, (g) Al Shorbagi Mosque, (h) Suq AL Khait (textiles), (i) Suq Al Atareen (spices), (j) Suq Aldahab (jewellery) and (k) Suq Al kharaz (beads and accessories).Pictures from a-i, source: F. Hussein; pictures $\mathrm{j}$ and k. Source: Heba Moanis.

\section{References}

1. Bandarin, F.E.C.; Van Oers, R.E. Reconnecting the City: The Historic Urban Landscape Approach and the Future of Urban Heritage; Bandarin, F., van Oers, R., Eds.; Wiley Blackwell: Chichester, UK, 2015.

2. Aysegul, K.T. Method for Assessment of the Historical Urban Landscape. Procedia Eng. 2016, 161, $1697-1703$. [CrossRef] 
3. Boyer, M.C. The City of Collective Memory: Its Historical Imagery and Architectural Entertainments; Boyer, M.C., Ed.; MIT Press: Cambridge, MA, USA, 1994.

4. Nassar, D.M.; Elcherif, I.A.; Naguib, I.M. Revitalizing the Commercial Heritage-A case study: "El-Manshya-Alexandria, Egypt". In Host of the Itinerant Congress Hidden Cultural Heritage: Under Water, Under Ground and Within Buildings (CICOP Italia), Proceedings of the 4th Biennial of Architectural and Urban Restoration, BRAU4, Beirut, Lebanon, 15-30 April 2018; COCIP: Firenze, Italy, 2018.

5. Coscia, C.; Lazzari, G.; Rubino, I. Values, Memory, and the Role of Exploratory Methods for Policy-Design Processes and the Sustainable Redevelopment of Waterfront Contexts: The Case of Officine Piaggio (Italy). Sustainability 2018, 10, 2989. [CrossRef]

6. Brundtland Commission. Our Common Future: World Commission on Environment and Development; Oxford University Press: Oxford, UK, 1987.

7. Rodwell, D. Conservation and sustainability in historic cities; John Wiley \& Sons: Hoboken, NJ, USA, 2007; Volume 22, ISBN 1405126566.

8. Eizenberg, E.; Jabareen, Y. Social Sustainability: A New Conceptual Framework. Sustainability 2017, 9, 68. [CrossRef]

9. Yung, E.H.K.; Chan, E.H.W.; Xu, Y. Sustainable Development and the Rehabilitation of a Historic Urban District-Social Sustainability in the Case of Tianzifang in Shanghai: Sustainable Development, Social, Rehabilitation Urban Historic Districts, Shanghai. Sustain. Dev. 2014, 22, 95-112. [CrossRef]

10. Littig, B.; Grießler, E. Social sustainability: A catchword between political pragmatism and social theory. Int. J. Sustain. Dev. 2005, 8, 14. [CrossRef]

11. Polese, M.; Stren, R. The Social Sustainability of Cities: Diversity and the Management of Change; Polese, M., Stren, R., Eds.; University of Toronto Press: Toronto, ON, Canada; Buffalo, NY, USA; London, UK, 2000.

12. Bramley, G.; Dempsey, N.; Power, S. What Is Sustainability and How Do Existing Urban Forms Perform in Nurturing It? Planning Research Conference: London, UK, 2006.

13. Colantonio, A. Social Sustainability: An Exploratory Analysis of Its Definition, Assessment Methods Metrics and Tools; EIBURS Working Paper Series (2007/01); Oxford Brooks University; Oxford Institute for Sustainable Development (OISD)—International Land Markets Group: Oxford, UK, 2007.

14. Colantonio, A. Traditional and Emerging Prospects in Social Sustainability. In Measuring Social Sustainability: Best Practice from Urban Renewal in the EU 2008/02; EIBURS Working Paper Series November 2008; Oxford Brooks University: Oxford, UK, 2008.

15. Jahanbakhsh, H.; Koumleh, M.H.; Alambaz, F.S. Methods and Techniques in Using Collective Memory in Urban Design: Achieving Social Sustainability in Urban Environments. Cumhur. Univ. Fac. Sci. J. CSJ 2015, $36,13$.

16. Molavi, M.; Rafizadeh Malekshah, E.; Rafizadeh Malekshah, E. Is collective memory impressed by urban elements? Manag. Res. Pract. 2017, 9, 14-27.

17. Darian-Smith, K.; Hamilton, P. Memory and History in Twentieth-Century Australia; Darian-Smith, K., Hamilton, P., Eds.; Oxford University Press: Melbourne, Australia, 1994.

18. Halbwachs, M. On Collective Memory; Edited, Translated, and with an Introduction by Coser, L.A.; Coser, L.A., Ed.; University of Chicago Press: Chicago, IL, USA, 1992.

19. Nora, P. Between memory and history: Les lieux de memoire. Mem. Count. Mem. 1989, 7-24. [CrossRef]

20. Hamilton, P. The Knife Edge: Debates about Memory and History. In Memory and History in Twentieth-Century Australia; Darian-Smith, K., Hamilton, P., Eds.; Oxford University Press: Melbourne, Australia, 1994; pp. 9-32.

21. INEE. INEE Thematic Issue Brief: Psychosocial Well-Being. Available online: http://www.humanitarianinfo. org/iasc/content/products (accessed on 11 May 2020).

22. Lynch, K. What Time Is This Place? MIT Press: Cambridge, MA, USA, 1972.

23. Lynch, K. A Theory of Good City Form; MIT Press: Cambridge, MA, USA, 1981.

24. Tuan, Y.-F. The Significance of the Artifact. Geogr. Rev. 1980, 70, 462-472. [CrossRef]

25. Hull, R.B.; Lam, M.H.C.; Vigo, G. Place identity: Symbols of self in the urban fabric. Landsc. Urban Plan. 1994, 28, 109-120. [CrossRef]

26. Jaskiewicz, M. Place attachment, place identity and aesthetic appraisal of urban landscape. Pol. Psychol. Bull. 2015, 46, 573-578. [CrossRef]

27. Lewicka, M. Place attachment, place identity, and place memory: Restoring the forgotten city past. J. Environ. Psychol. 2008, 28, 209-231. [CrossRef] 
28. Relph, E.C. Place and Placelessness; A revision of the author's thesis; University of Toronto: Toronto, ON, Canada, 1976.

29. Misztal, B.A. Collective Memory in a Global Age: Learning How and What to Remember. Curr. Sociol. 2010, 58, 24-44. [CrossRef]

30. Lak, A.; Hakimian, P. Collective memory and urban regeneration in urban spaces: Reproducing memories in Baharestan Square, city of Tehran, Iran. Cityculture Soc. 2019, 18, 100290. [CrossRef]

31. Steele, F. The Sense of Place; CBI Pub. Co.: Boston, MA, USA, 1981.

32. Eyles, J. Senses of Place; Silverbrook Press: Warrington, UK, 1985.

33. Jackson, J.B. A Sense of Place, a Sense of Time; Yale University Press: New Haven, CT, USA, 1994.

34. Hay, R. Sense of Place in Developmental Context. J. Environ. Psychol. 1998, 18, 5-29. [CrossRef]

35. Shamai, S.; Ilatov, Z. Measuring Sense of Place: Methodological Aspects. Tijdschr. Econ. Soc. Geogr. 2005, 96, 467-476. [CrossRef]

36. Punter, J. The Design Dimension of Planning: Theory, Content and Best Practice for Design Policies, 1st ed.; Carmona, M., Ed.; E. \& F.N. Spon: London, UK, 1997.

37. Williams, D.R.; Stewart, S.I. Sense of place: An elusive concept that is finding a place in ecosystem management. J. For. 1998, 66, 18-23.

38. Eisenhauer, B.; Krannich, R.; Blahna, D. Attachments to Special Places on Public Lands: An Analysis of Activities, Reason for Attachments, and Community Connections. Soc. Nat. Resour. 2000, 13, 421-441.

39. Lim, W.S.-W. Memories and urban places. Anal. Urban Trends Cult. Theory Policy Action 2000, 4, $270-277$. [CrossRef]

40. Hussein, F.; Stephens, J.; Tiwari, R. Cultural Memories for Better Place Experience: The Case of Orabi Square in Alexandria, Egypt. Urban Sci. 2020, 4, 14. [CrossRef]

41. Hussein, F.; Stephens, J.; Tiwari, R. Cultural Memories and Sense of Place in Historic Urban Landscapes: The Case of Masrah Al Salam, the Demolished Theatre Context in Alexandria, Egypt. Land 2020, 9, 264. [CrossRef]

42. Al-Hagla, K.S. Cultural Sustainability: An Asset of Cultural Tourism Industry. Work. Pap. 2005, 6, 6-12.

43. Alexandria Portal. Available online: http://www.alexandria.gov.eg/Alex/english/index.aspx (accessed on 8 September 2019).

44. Hanafi, M.A.M. Development and Conservation with Special Reference to the Turkish Town of Alexandria; University of York: York, UK, 1993.

45. Asem, D. El Zanqa Market. A Folkloric Painting Drawn by the Alexandrian Traditional Girls (Arabic Source). Available online: http://archive.aawsat.com/details.asp? section $=67$ \&article $=512941$ \&issueno= 11080\#.WG0ZL027rug (accessed on 2 January 2017).

46. Morse, J.M. Designing funded qualitative research. In Handbook of Qualitative Research; Denzin, N.K., Lincoln, Y.S., Eds.; Sage Publications Ltd.: Thousand Oaks, CA, USA, 1994; pp. 220-235.

47. Gregory, J. Connecting with the past through social media: The 'Beautiful buildings and cool places Perth has lost' Facebook group. Int. J. Herit. Stud. 2015, 21, 22-45. [CrossRef]

48. Van der Hoeven, A. Historic urban landscapes on social media: The contributions of online narrative practices to urban heritage conservation. City Cult. Soc. 2019, 17, 61-68. [CrossRef]

49. Wilson, K.; Desha, C. Engaging in design activism and communicating cultural significance through contemporary heritage storytelling: A case study in Brisbane, Australia. J. Cult. Herit. Manag. Sustain. Dev. 2016, 6, 271-286. [CrossRef]

50. Zhou, W. Residents' Collective Memory of Urban Street and Lane Spaces: A Case Study of the Confucius Temple Block in Nanjing City. J. Landsc. Res. 2016, 8, 61.

51. Olsen, W. Triangulation in Social Research: Qualitative and Quantitative Methods Can Really Be Mixed. In Developments in Sociology; Holborn, M., Ormiskirk, Eds.; Causeway Press: Ormskirk, Lancashire, UK, 2004.

52. Krippendorff, K. Content Analysis: An. Introduction to Its Methodology, 2nd ed.; Sage Publications Ltd.: Thousand Oaks, CA, USA, 2004.

53. Lynch, K. The Image of the City; MIT Press: Cambridge, MA, USA, 1960.

54. Cross, J.E. What Is Sense of Place? In Proceedings of the 12th Headwaters Conference, Western State College, Gunnison, CO, USA, 2-4 November 2001.

55. Ardakani, M.K.; Oloonabadi, S.S.A. Collective memory as an efficient agent in sustainable urban conservation. Procedia Eng. 2011, 21, 985-988. [CrossRef] 
56. Jones, O. Geography, memory and non-representational geographies. Geogr. Compass 2011, 5, 875-885. [CrossRef]

57. Kansteiner, W. Finding Meaning in Memory: A Methodological Critique of Collective Memory Studies. Hist. Theory 2002, 41, 179-197. [CrossRef]

58. Anton, C.E.; Lawrence, C. Home is where the heart is: The effect of place of residence on place attachment and community participation. J. Environ. Psychol. 2014, 40, 451-461. [CrossRef]

59. Hoteit, A. Role of the Landscape in the Preservation of Collective Memory and the Enhancement of National Belonging. Can. Soc. Sci. 2015, 11, 42-49.

60. Knez, I.; Eliasson, I. Relationships between Personal and Collective Place Identity and Well-Being in Mountain Communities. Front. Psychol. 2017, 8, 79. [CrossRef] [PubMed]

61. Legg, S. Memory and Nostalgia; Sage Publications Ltd.: London, UK, 2004; pp. 99-107.

62. Fenster, T.; Misgav, C. Memory and place in participatory planning. Plan. Theory Pract. 2014, 15, 349-369. [CrossRef]

(C) 2020 by the authors. Licensee MDPI, Basel, Switzerland. This article is an open access article distributed under the terms and conditions of the Creative Commons Attribution (CC BY) license (http://creativecommons.org/licenses/by/4.0/). 